\title{
PLAN DE COMUNICACIÓN: UN BUEN INSTRUMENTO PARA QUE SU CAMPAÑA TENGA ÉXITO ${ }^{1}$
}

\section{COMMUNICATION PLAN: A GOOD INSTRUMENT FOR A SUCCESSFUL CAMPAIGN ${ }^{1}$}

\author{
Paola Páez², Ligia Rodríguez ${ }^{3}$
}

\begin{abstract}
RESUMEN
Plan de comunicación: un buen instrumento para que su campaña tenga éxito. Se describe la metodología empleada para el diseño de un plan de comunicación de una Campaña para incrementar el consumo de frijoles, en una comunidad urbana de Costa Rica. Un diagnóstico previo, complementado con las pruebas de comportamiento, fueron los insumos de los que se partió para obtener la información preliminar, necesaria para generar las ideas centrales de los mensajes que deberían ser difundidos a la población. Con base en esa información y retomando algunas condiciones preestablecidas por el proyecto, se elaboró el plan de comunicación (versión I). Por otra parte, a partir de las ideas centrales se formularon y probaron los contenidos de los mensajes y los definitivos se integraron a ese plan. Finalmente un análisis grupal permitió revisar y generar el plan de comunicación definitivo (Versión II). Se describe el proceso que gradualmente se sigue para formular el plan de comunicación y se hace énfasis sobre la importancia del trabajo en equipo y sobre el conocimiento directo que se debe tener de la población sujeto de estudio. El plan de comunicación, resulta ser un instrumento fundamental para la elaboración y ejecución del plan de la Campaña, así como para su evaluación.
\end{abstract}

Palabras claves: Campaña, frijoles, mensajes, plan de comunicación.

\begin{abstract}
Communication plan: a good instrument for a successful campaign. The methodology used to design a communication plan for a Campaign to increase bean consumption in a Costa Rican urban community is described in this article. Results of an initial assessment, complemented with behavior tests, were the input used to obtain the preliminary information necessary to generate main ideas for the messages to be disseminated throughout the population. The communication plan (Version I) was designed based on this information and on conditions previously established by the Project. On the other hand, the contents for messages were drawn up, tested, and integrated into the plan, based on the main ideas. Then, the final communication plan (Version II) was the result of a group analysis. The process to design the communication plan is described emphasizing on the importance of team work and the direct knowledge of the population under study. The communication plan is a fundamental instrument to plan, implement, and evaluate the Campaign.
\end{abstract}

Key words: Campaign, beans, messages, communication plan.

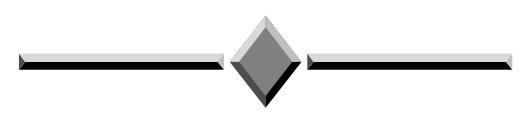

1 Recibido para publicación el 25 de junio del 2004. Este artículo se deriva de la investigación desarrollada en el "Proyecto Campaña Educativa para Incrementar el Consumo de Frijoles", de la Escuela de Nutrición de la UCR, inscrito dentro del proyecto macro "Mejoramiento de la Digestibilidad del Frijol", CITA-UCR, bajo el auspicio del Programa Bean/Cowpea CRSP; USAID Grant DAN-G-SS-86-0008-88.

2 Escuela de Nutrición, Universidad de Costa Rica. E-mail: pabolap@iastates.edu

3 Escuela de Nutrición, Universidad de Costa Rica. Investigadora principal del "Proyecto Campaña Educativa para incrementar el consumo de frijoles". E-mail: farodri@ racsa.co.cr
1 Received for publication on June 25, 2004. This article is the result from the investigation carried out in the Project "Educational Campaign to Increase Bean Consumption", from the University of Costa Rica's Nutrition School, which is part of the macro-project "Improving Digestibility of Beans", CITA, UCR, sponsored by the Bean/Cowpea CRSP Program; USAID Grant DAN-G-SS-86-0008-88.

2 University of Costa Rica, Nutrition School. E-mail: pabolap@iastates.edu

3 University of Costa Rica, School of Nutrition. Principal Researcher Project "Educational Campaign to Increase Bean Consumption”. E-mail: farodri@racsa.co.cr 


\section{INTRODUCCIÓN}

Los hábitos alimentarios de la población de Costa Rica, principalmente de las áreas urbanas, se han modificado considerablemente (INCAP/ICNND/ Ministerio de Salubridad Pública de Costa Rica 1969, Ministerio de Salud 1979, Ministerio de Salud 1986, Ministerio de Salud 1996). Muchos de esos cambios, han tenido consecuencias negativas para la alimentación del costarricense. Es necesario, por lo tanto, utilizar diferentes estrategias de comunicación que permitan rescatar los hábitos alimentarios tradicionales, particularmente aquellos que propician el consumo de alimentos nutricionalmente valiosos. Tal es el caso de los frijoles que han constituido un alimento básico, cuyo consumo ha disminuido principalmente en la zona urbana. Además, como indica Schetjman (1994), el mercado de alimentos tradicionales se mantiene por sí mismo, con poca o ninguna propaganda.

Esta situación motivó el desarrollo de un proyecto denominado "Campaña Educativa para Incrementar el Consumo de Frijoles". Dicho proyecto realizó inicialmente, un diagnóstico (Campos et al. 1999), al que le siguió una etapa de definición de los contenidos de los mensajes durante la cual se elaboró un plan de comunicación. Este constituyó un elemento indispensable para desarrollar el plan de campaña, la ejecución del mismo y su evaluación posterior.

El artículo tiene como propósito documentar el proceso desarrollado para elaborar el plan de comunicación. Este constituyó parte del Trabajo Final de Graduación "Elaboración de los Contenidos de los Mensajes de una Campaña Educativa para Incrementar el Consumo de Frijoles en una Comunidad Urbana" (Martínez et al. 2000).

\section{MATERIALES Y MÉTODOS}

El primer paso para elaborar el plan de comunicación fue la revisión del trabajo del diagnóstico (Campos et al. 1999). De ese trabajo se extrajeron las prácticas reales de la población con respecto a la compra, el almacenamiento, la preparación y el consumo de frijoles. A partir de esas prácticas reales y con el apoyo de revisión bibliográfica, el grupo a cargo de la investigación discutió y propuso una serie de prácticas ideales o sean aquellas que se consideraban como las más convenientes para preservar al valor nutritivo y favorecer un mayor consumo de frijoles.

Esas prácticas ideales propuestas fueron sometidas a la revisión de un grupo interdisciplinario de especialistas,

\section{INTRODUCTION}

Eating habits of the Costa Rican population, mainly in urban areas, have undergone considerable changes (INCAP/ICNND/ Ministerio de Salubridad Pública de Costa Rica 1969, Ministerio de Salud 1979, Ministerio de Salud 1986, Ministerio de Salud 1996). Many of these changes have had negative consequences on the nutrition of Costa Ricans. Therefore, different communication strategies must be used to strengthen traditional eating habits, in particular those that favor consumption of nutritionally valuable foods. Such is the case of beans, which have been a staple food for Costa Ricans, but their consumption has decreased especially in urban areas. Moreover, as Schetjman (1994) indicates, the traditional food market sustains itself with little or no advertisement whatsoever.

This motivated the implementation of a Project entitled "Educational Campaign to Increase Bean Consumption". Initially, an assessment was made (Campos, Fernández, Sánchez, Sancho, and Villalobos, 1999), followed by a message definition phase, during which the communication plan was designed. This instrument was an essential element to plan, implement, and evaluate the Campaign.

This article documents the process to design the communication plan, which was part of the Final Graduation Paper "Elaboración de los Contenidos de los Mensajes de una Campaña Educativa para Incrementar el Consumo de Frijoles en una Comunidad Urbana de Clase Media" (Writting of Contents for Messages in an Educational Campaign to Increase Bean Consumption in a Middle-Class Urban Community in Costa Rica) (Martínez et al. 2000).

\section{MATERIALS AND METHODS}

The first step for designing the plan was a revision of the initial assessment (Campos et al. 1999). Actual practices of the population with regards to bean purchase, preservation, preparation, and consumption were drawn out from this work. Starting with this actual practices, and a bibliographical review, the research team discussed and proposed a series of ideal practices, i.e., those considered to be the most convenient to preserve the nutritional value of beans, and increase their consumption.

These proposed ideal practices were reviewed by an interdisciplinary team of specialists who suggested modifications according to their experience and technical criteria. 
quienes sugirieron modificaciones de acuerdo con su experiencia y criterio técnico.

Finalmente, las prácticas ideales resultantes, fueron sometidas a "pruebas de comportamiento", tal como fue descrito por Dumani y Rodríguez (2004). Es importante indicar que dichas pruebas fueron realizadas por el mismo grupo de investigación a cargo de elaborar el plan de comunicación. Esto permitió un acercamiento muy valioso a la comunidad y particularmente a las madres que constituían el grupo objetivo de la Campaña.

El diagnóstico, complementado con las pruebas de comportamiento, fueron los insumos básicos para la construcción del plan de comunicación. El esquema 1 presenta un flujograma del proceso seguido en su elaboración.

Puede observarse que, con base en los insumos mencionados, se obtuvo una información preeliminar que generó como resultado las "ideas centrales de los mensajes". La información preeliminar, junto con algunas condiciones preestablecidas por el proyecto, dieron origen a una primera versión del plan de comunicación (I). Paralelamente, las "ideas centrales de los mensajes" se formularon como "contenido de los mensajes" y se validaron con la población, lo que dió como resultado los "mensajes a emitir". Esos mensajes se incorporaron al plan de comunicación. Seguidamente, el

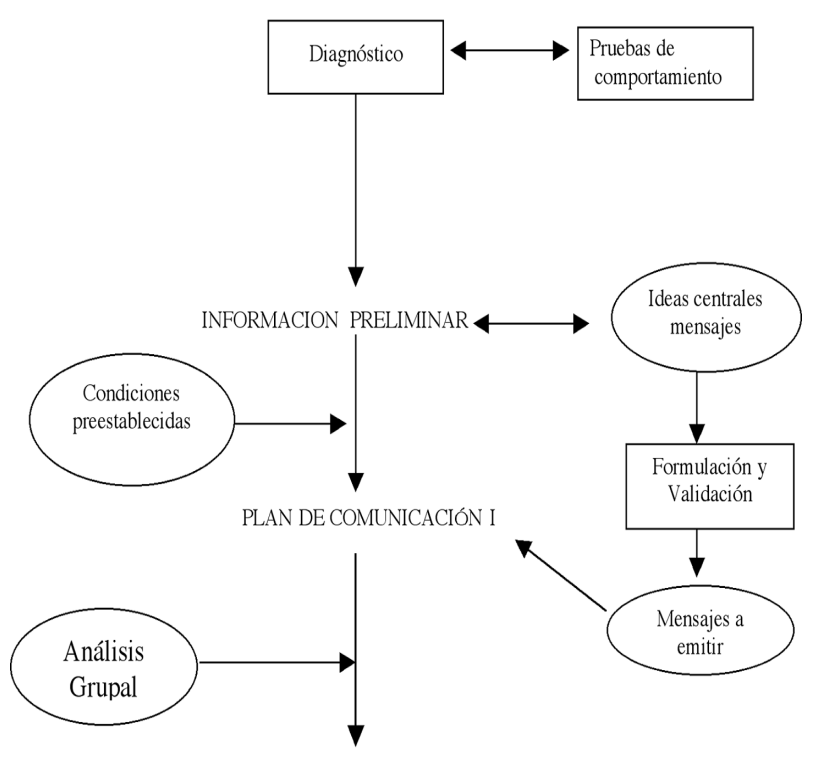

PLAN DE COMUNICACIÓN II

Esquema 1. Proceso de elaboración del plan de comunicación Campaña Educativa para incrementar el consumo de frijoles. Sabanilla de Montes de Oca, Costa Rica, 1999-2000.
Finally, the resulting ideal practices were subjected to "behavior tests", as described by Dumani and Rodríguez (2004). It is important to indicate that these behavior tests were carried out by the same research group in charge of designing the communication plan. This facilitated establishing a valuable close relationship with the community, and particularly with the mothers that were the target group of the Campaign.

The initial assessment, complemented with behavior tests, was the basic input used to design the communication plan. A flowchart of the process is presented in Diagram 1.

As may be noted, the preliminary information was obtained from the above mentioned inputs, and the "main ideas for the messages" were generated from them. Version I for the communication plan was based on the preliminary information, and some conditions previously established by the Project. In parallel, the "main ideas for the messages" were written as "contents for messages" that were validated with the population, resulting in the "messages to be delivered". These messages were integrated into the plan. Next, the communication plan (Version I) underwent a group analysis involving researchers, team members in charge of the Project, and some specialists on the subject, to generate the final communication plan (Version II).

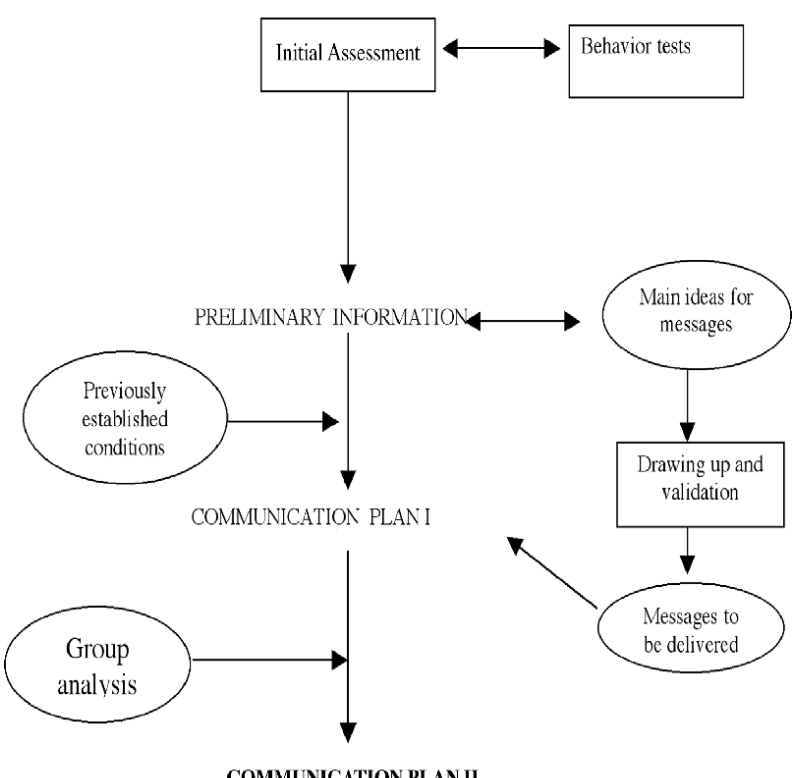

Diagram 1. Process to design the communication plan Educational Campaign to increase bean consumption. Sabanilla de Montes de Oca, Costa Rica, 1999-2000. 
plan de comunicación (versión I) se sometió a un análisis grupal, en el que participaron los investigadores, los miembros del equipo a cargo del proyecto y especialistas en la temática; lo que generó el plan de comunicación II, o definitivo.

El formato seguido para organizar la información preliminar, requerida para elaborar el plan se presenta en el Cuadro 1.

Cuadro 1. Información preliminar para la elaboración del plan de comunicación. Campaña educativa para incrementar el consumo de frijoles. Sabanilla de Montes de Oca, Costa Rica, 1999.

\begin{tabular}{|c|c|c|}
\hline $\begin{array}{c}\text { Conocimientos, } \\
\text { actitudes y prácticas } \\
\text { extraídas del } \\
\text { diagnóstico }\end{array}$ & $\begin{array}{c}\text { Forma de } \\
\text { rechazarlo, } \\
\text { reafirmarlo o } \\
\text { corregirlo }\end{array}$ & $\begin{array}{c}\text { Ideas centrales } \\
\text { de los contenidos } \\
\text { de los mensajes }\end{array}$ \\
\hline & & \\
\hline
\end{tabular}

Fuente: Martínez et al. 2000.

El diagnóstico inicial (Campos et al. 1999; Rodríguez y Rodríguez 2003; Murillo y Rodríguez 2004; Rodríguez y Murillo 2004a) y el estudio de las pruebas de comportamiento (Rodríguez y Murillo 2004b), aportaron información sobre los conocimientos, actitudes y prácticas (CAPs) que la población tenía con respecto a los frijoles. Luego, los CAPs se confirmaban, rechazaban o modificaban, de acuerdo a los argumentos científicos correspondientes, es decir a lo que se había determinado como "ideal o recomendable" ( $2^{\mathrm{a}}$ columna). De esas dos primeras columnas se obtuvieron las ideas centrales de los mensajes que se consideró necesario difundir a la población ( $3^{\mathrm{a}}$ columna). El flujograma del proceso (Esquema 1) destaca ese aporte de la información preliminar.

El plan de comunicación (versión I), se fundamentó en la información preliminar ya descrita y en algunas condiciones preestablecidas por el proyecto: el objetivo general, los grupos o audiencias a los que se dirigiría la Campaña y la estrategia de comunicación. El objetivo general fue "incrementar el consumo de frijoles". Los grupos a los que se dirigiría la Campaña fueron: las madres de niños y niñas escolares (grupo objetivo), los escolares de tercer y cuarto grados (grupo interactivo) y los líderes comunales, maestros y personal local de
The format used to organize the preliminary information required to design the plan is presented in Table 1.

Table 1. Preliminary information to design the communication plan. Educational Campaign to increase bean consumption Sabanilla de Montes de Oca, Costa Rica, 1999.

\begin{tabular}{|c|c|c|}
\hline $\begin{array}{c}\text { Knowledge, attitudes, } \\
\text { and practices drawn out } \\
\text { from initial assessment }\end{array}$ & $\begin{array}{c}\text { Ways to } \\
\text { reinforce, reject, } \\
\text { or modify them }\end{array}$ & $\begin{array}{c}\text { Main ideas for } \\
\text { message content }\end{array}$ \\
\hline & & \\
\hline
\end{tabular}

Source: Martínez et al. 2000.

The initial assessment (Campos et al. 1999, Rodríguez and Rodríguez 2003; Murillo and Rodríguez 2004; Rodríguez and Murillo 2004a), and the analysis of behavior tests (Rodríguez and Murillo 2004b) provided information about the population's knowledge, attitudes, and practices (KAPs) with regards to beans. This information was placed in Column 1 of Table 1. Then, the KAPs were reinforced, rejected, or modified, according to the corresponding scientific arguments, i. e., depending on what had been defined as "ideal or recommended" (Column 2). The main ideas for the messages (Column 3) were drawn out from these first two columns. The process flowchart (Diagram 1) highlights that contribution from preliminary information.

The communication plan (Version I), was based on the preliminary information described above, and on conditions previously established by the Project, including the general objective, the Campaign's target groups or audience, and the communication strategy. The general objective was to "increase bean consumption". The target groups were the mothers of school children (target group), third - and fourth-grade school children (interactive group), and community leaders, teachers, and local health-care personnel (support group); each one of these groups was a particular audience. On the other hand, given that the Project had been conceived as an educational campaign, the multimedia and interpersonal communication strategy was also regarded as a previously established condition. 
salud (grupo de apoyo). Estos grupos correspondían cada uno, a una audiencia particular. Otra condición preestablecida dado que el proyecto había sido planteado como una campaña educativa, fue la estrategia de multimedios y comunicación interpersonal.

El plan de comunicación se elaboró para cada una de las audiencias, de manera que se adaptara a las características y perfil de cada grupo en particular. En el Cuadro 2 se presenta la matriz utilizada para el diseño del plan de comunicación.

Como puede observarse, antes de la matriz se indican: la audiencia, la estrategia de comunicación y el objetivo general, previamente establecidos.

La siguiente tarea fue la definición de los objetivos específicos, que debían enmarcarse en esas condiciones preestablecidas y basarse en la información preliminar (Cuadro 1 y Esquema 1). Para facilitar la definición y lograr mayor especificidad, estos objetivos se establecieron como: objetivos dirigidos a informar a la población, objetivos relacionados con actitudes y objetivos para reforzar o modificar comportamientos existentes.

Para cada uno de los objetivos específicos propuestos se identificaron en las siguientes dos columnas,
The communication plan was designed for each one of the audiences, so that it would fit the characteristics and profile of each particular group. The matrix used to design the communication plan is shown in Table 2.

As may be seen, the audience, the communication strategy, and the general objective previously established, are indicated above the matrix.

The next task was to define specific objectives, according to the previously established conditions, and preliminary information (see Table 1 and Diagram 1). In order to achieve a greater specificity, these objectives were defined as: those aimed at informing the population, those aimed at changing attitudes, and those aimed at reinforcing or modifying existing behaviors.

The barriers and incentives for the proposed changes - drawn out from the "preliminary information" - were identified for each one of the specific objectives, and included in the next two columns.

Once the objectives were established, as well as the barriers and incentives to change for each one of the

Cuadro 2. Matriz del plan de comunicación. Campaña educativa para incrementar el consumo de frijoles. Sabanilla de Montes de Oca, Costa Rica, 1999.

Audiencia: grupo correspondiente

Estrategia de comunicación: Comunicación por multimedios e interpersonal

Objetivo general: Aumentar el consumo de frijoles en la comunidad de Sabanilla

\begin{tabular}{|c|c|c|c|c|}
\hline Objetivos & $\begin{array}{c}\text { Barreras para el } \\
\text { cambio }\end{array}$ & $\begin{array}{c}\text { Incentivos para el } \\
\text { cambio }\end{array}$ & $\begin{array}{c}\text { Ideas centrales de } \\
\text { los mensajes }\end{array}$ & Indicador de éxito \\
\hline & & & & \\
\hline
\end{tabular}

Fuente Martínez et al. 2000.

Table 2. Matrix for the communication plan. Educational Campaign to increase bean consumption Sabanilla de Montes de Oca, Costa Rica, 1999.

Audience: Corresponding group

Communication strategy: Multimedia and interpersonal communication

General objective: To increase bean consumption in the community of Sabanilla

\begin{tabular}{|c|c|c|c|c|}
\hline Objectives & $\begin{array}{c}\text { Barriers to } \\
\text { change }\end{array}$ & $\begin{array}{c}\text { Incentives to } \\
\text { change }\end{array}$ & $\begin{array}{c}\text { Main ideas for } \\
\text { messages }\end{array}$ & $\begin{array}{c}\text { Success } \\
\text { indicators }\end{array}$ \\
\hline & & & & \\
\hline
\end{tabular}

Source: Martínez et al. 2000. 
las barreras e incentivos para el cambio planteado, obtenidos de la "información preliminar".

Los objetivos definidos, las barreras y los motivadores para el cambio, de cada una de las audiencias a abordar, permitieron ubicar en la matriz del plan de comunicación (Cuadro 2), las "ideas centrales de los mensajes", las cuales también se extrajeron de la información preliminar. Por último, la columna "Indicador de éxito" se elaboró planteando para cada uno de los objetivos específicos, los resultados que se esperaba obtener después de la Campaña.

Paralelamente, el mismo grupo de investigación, con base en las "ideas centrales de los mensajes", formuló los contenidos de los mensajes para las diferentes audiencias, utilizando el lenguaje popular con respecto a los frijoles. Para ello se siguieron los criterios recomendados por FAO (1996): que fueran breves y sencillos; que dieran información confiable y concreta; que recomendaran cambios precisos (en el caso de prácticas) y que utilizaran expresiones positivas.

El resultado fue la obtención de los contenidos de 14 mensajes, de los cuales seis fueron grabados y ocho fueron escritos en cartulina blanca con letra imprenta y enmarcados en cartulina de colores varios, a fin de someterlos a validación por la población.

La validación de los contenidos de los mensajes incluyó las siguientes variables:

comprensión - si entiende o no los contenidos de los mensajes;

atracción - si se siente atraído (a), interesado (a), agradado (a) o no por el mensaje;

identificación - si hay identificación, afinidad, o no con los contenidos de los mensajes;

persuasión - si la audiencia identifica lo que debe hacer y está convencida o no de hacerlo.

Previo a la validación de los contenidos de los mensajes, el equipo de investigación recibió una capacitación, que culminó con la prueba de los diferentes instrumentos que serían utilizados en la misma. Esta prueba se realizó en una población urbana, similar a la de Sabanilla.

La validación de los contenidos de los mensajes se efectuó en Sabanilla de Montes de Oca, con las diferentes audiencias: madres de escolares, escolares y líderes comunales. Se realizaron grupos de discusión con los dos primeros y entrevistas semiestructuradas con los últimos. Durante el proceso, para evitar la monotonía, se alternaban mensajes escritos con mensajes verbales grabados. audiences to be reached, it was possible to place the "main ideas for the messages" - also obtained from the preliminary information - within the matrix for the communication plan. Finally, the "Success indicator" column was defined according to the expected effects of the Campaign for each one of the specific objectives.

In parallel, based on the "main ideas for messages", the same research team phrased the contents of messages for the different audiences, using the popular language with respect to beans. For this purpose, FAO's recommended criteria (1996) were followed: messages have to be short and simple, provide reliable and concrete information, recommend specific changes (in the case of practices), and use positive expressions.

As a result, the contents for 14 messages were produced, six of which were recorded, and eight were written on white cardboard with printed letters. These were framed in cardboard of different colors, to be validated by the population.

The content of the messages was validated taking into consideration the following variables:

Understanding - whether or not message content was understandable;

Appeal - whether or not people were drawn to, interested and pleased by the messages;

Identification - whether or not people felt identified with or related to message content;

Persuasion - whether or not people in the audience identified what they should do, and felt convinced to do it.

Team members were trained to validate the contents of messages, including testing of the different instruments to be used in the research. These previous tests were carried out in an urban population, similar to that of Sabanilla.

The messages' contents were validated in Sabanilla de Montes de Oca, with the different audiences: mothers of school children, school children, and community leaders. There were discussion groups with the first two, and semi-structured interviews with the last one. In order to avoid boredom during the process, written messages were alternated with recorded verbal messages.

Validation of the contents for messages facilitated making changes in their form and content, in order to define effective "messages to be delivered". These replace the column "central ideas for the messages" in 
Los resultados de la validación de los contenidos de los mensajes permitieron hacer cambios de forma $y$ contenido en los mismos para obtener "mensajes a emitir" que fueran efectivos. Estos sustituyeron la columna "ideas centrales de los mensajes" en la matriz del plan de comunicación y se utilizaron en la elaboración de los materiales y mensajes radiales para la Campaña y en las actividades interactivas con la población.

El plan de comunicación (I) del trabajo de Martínez et al. (2000), con los "mensajes a emitir" fue sometida a un análisis grupal, por parte de las investigadoras y del equipo de trabajo del proyecto ${ }^{4}$. Es necesario recordar que el objetivo general del proyecto era "incrementar el consumo de frijoles". El análisis se realizó en función de la coherencia o no de los diferentes elementos (contenidos en el Cuadro 2), con el objetivo general. También se consideró el grado de contribución de esos elementos a ese mismo objetivo.

El análisis permitió depurar el plan de comunicación (versión I), eliminando aquellos elementos poco importantes y dando énfasis a aquellos que sí lo eran para lograr el objetivo. Esta actividad también contribuyó a corregir el vocabulario empleado en los mensajes principalmente en aquellos casos en que se había mantenido el lenguaje técnico y no el popular. Por ejemplo "cocinar frijoles" fue sustituido por "poner frijoles" y "consumir frijoles" por "comer frijoles".

Finalmente se obtuvo el plan de comunicación (II), que es lo que puede observarse como último eslabón en el flujograma del proceso. Este plan fue el que se utilizó para la planificación y evaluación de la Campaña.

\section{RESULTADOS Y DISCUSIÓN}

El proceso metodológico anteriormente descrito dio como resultado el plan de comunicación definitivo. Este aportó elementos indispensables para la planificación de la Campaña, ya que permitió definir las actividades y determinar los materiales que serían requeridos. Ambos elementos (el plan de comunicación y el plan de Campaña) fueron de gran utilidad para la Campaña. En la etapa previa, permitieron ordenar la producción de los materiales, organizar las actividades y establecer los nexos necesarios. En la etapa de ejecución constituyeron el marco orientador de la Campaña. Finalmente, en la etapa de evaluación, los indicadores de éxito del plan de comunicación, constituyeron los

\footnotetext{
4 Equipo de trabajo del Proyecto: tres nutricionistas, una comunicadora y una psicóloga.
}

the communication plan and were used to prepare the materials and radio messages for the Campaign, and for the interactive activities with the population.

The communication plan (I) from the work of Martínez et al (2000), with the "messages to be delivered" was subjected to a group analysis by the researchers and Project work team ${ }^{4}$. It is important to bear in mind that the Project's general objective was to "increase bean consumption". The analysis was made based on the consistency or inconsistency of the different elements (included in Table 2), with the general objective. The degree of contribution of such elements to the same objective was also analyzed.

As a result of the analysis, the communication plan (Version I) was improved, discarding unimportant elements, and emphasizing on those that were important to achieve the objective. It also made it possible to improve the vocabulary used in the messages, mainly in those cases in which technical, rather than popular language, had been used. For instance, "to cook beans" was replaced by "to make beans", and "to consume beans" was replaced by "to eat beans".

Finally, the communication plan (II) was drawn up, and it is the last link in the flowchart (Diagram 1). This communication was used to plan, implement, and evaluate the Campaign.

\section{RESULTS AND DISCUSSION}

The methodological process described above resulted in the final communication plan. This plan provided critical elements for planning the Campaign, since it permitted defining the activities and required materials. Both instruments (the communication plan and the plan for the Campaign) were greatly useful for the Campaign. During the previous phase, they were used to request preparation of materials, organize the activities to be implemented, and establish the necessary links with the different actors. In the course of implementation, they were the guiding framework for the Campaign. Finally, during evaluation, the success indicators of the communication plan were the standards used to assess the actions. As an example, Table 3 shows part of the communication plan designed for the target group.

\footnotetext{
4 Project's work team: three nutritionists, a communicator, and a psychologist.
} 
parámetros para evaluar la intervención. En el Cuadro 3 se muestra, como ejemplo, parte de la matriz del plan de comunicación elaborada para el grupo objetivo.

Los objetivos son los que definen lo que el plan se propone alcanzar. Correspondieron a la primera columna de la matriz y se plantearon de acuerdo con la población o audiencia a la cual iban dirigidos, por lo que fue necesario la definición previa de las audiencias.

Las barreras e incentivos para el cambio constituían información indispensable para que la propuesta tuviera éxito. Para ello, fue necesario identificar para cada objetivo, las barreras que podrían limitar la incorporación de las modificaciones y los aspectos que podrían motivar a la población para alcanzar los objetivos planteados ( $2^{\text {da }}$ y $3^{\text {era }}$ columna).

Los mensajes a ser emitidos ( $4^{\text {ta }}$ columna), constituyeron la columna central para la intervención. Una de las premisas en este trabajo, es que las personas aprenden mejor si parten de su experiencia previa (Díaz-Barriga y Hernández 2002). De esta manera, los conocimientos, las actitudes y las prácticas de la población, cuando son correctas, pueden ser reafirmadas; modificadas cuando son parcialmente incorrectas, o rechazadas cuando resultan perjudiciales o inadecuadas (Bourges 1988). La valoración que se haga sobre lo adecuado o inadecuado de una práctica, un conocimiento o una actitud implica una gran responsabilidad desde el punto de vista educativo y por ello deben estar muy claros los fundamentos científicos que dan pie a dicha valoración. Por otra parte, la metodología cualitativa profundiza en el estudio socio-cultural de la población, lo que permite contar con un criterio más amplio al decidir si un comportamiento, una actitud o una práctica es o no adecuada en el contexto particular. En este caso, tal como ha sido descrito, ambos criterios se incorporaron al definir las ideas centrales de los mensajes.

Finalmente, en la última columna de la matriz se ubicaron los indicadores de éxito.

En conclusión, el proceso garantizó la utilización de los resultados del diagnóstico e hizo que el plan de comunicación, al fundamentarse sobre una base real, constituyera un excelente marco de referencia y una guía para la planificación, ejecución y evaluación de la Campaña.

Los resultados positivos de la evaluación de la Campaña (Dumani y Páez 2004; Rodríguez 2004; Rodríguez y Páez 2004) permiten indicar que el diseño del plan de comunicación, fundamenta y facilita el proceso, por lo que constituye un valioso instrumento para el desarrollo de proyectos educativos.
The objectives actually define what the plan is intended to achieve. The objectives are in the first column of the matrix and were proposed according to the population or audience they targeted. For this reason, it was necessary to define the audiences previously.

The barriers and incentives to change are critical for the proposal to succeed. Consequently, it was necessary to identify - for each objective - the barriers that could hinder introducing the changes, and aspects that might motivate the population, in order to achieve the proposed objectives ( $2^{\text {nd }} y 3^{\text {th }}$ columns).

The messages to be delivered ( $4^{\text {th }}$ column) are the backbone of the actions. One of the assumptions of this work is that people learn better if they start from their own previous experience (Díaz-Barriga and Hernández 2002). Thus, when people's knowledge, actual attitudes, and practices are adequate, they may be reinforced; when they are partially inadequate, they may be modified; and when they are inadequate or harmful, they may be rejected (Bourges 1988). Assessing whether a specific knowledge, attitude, or practice is adequate or not entails a great responsibility from the educational point of view, and therefore the scientific basis for such assessment must be clear. On the other hand, a qualitative approach facilitates a deeper understanding of people's socio-cultural background, and a wider perspective when deciding whether a specific knowledge, attitude, or practice is adequate or not in a particular context. As described before, in this case both criteria were taken into account when defining the main ideas for the messages.

Finally, the success indicators are placed in the last column of the matrix.

In conclusion, following the process ensured use of information from the initial assessment, and the communication plan - since it was based on reality was a good framework and guiding instrument for planning, implementing, and evaluating the Campaign.

The results from the Campaign's final evaluation (Dumani and Páez 2004; Rodríguez 2004; Rodríguez and Páez 2004) indicate that the design of a communication plan provides the foundations for the process and facilitates it. Hence, it constitutes a valuable instrument for implementing educational projects.

This experience is greatly useful to improve specific aspects of eating habits, either to introduce or increase consumption of a functional food (American Dietetic Association 1999) such as beans, or to decrease the consumption of unhealthful foods. By 
Cuadro 3. Parte de la matriz plan de comunicación para el grupo objetivo. Campaña educativa para incrementar el consumo de frijoles. Sabanilla de Montes de Oca, Costa Rica, 2000.

Audiencia: Madres con niños escolares

Estrategia de comunicación: Interpersonal y por multimedios

Objetivo general: Aumentar el consumo de frijoles en la comunidad de Sabanilla

\begin{tabular}{|c|c|c|c|c|}
\hline Objetivos & Barreras para el cambio & $\begin{array}{c}\text { Incentivos para el } \\
\text { cambio }\end{array}$ & Mensajes a ser emitidos & Indicador de éxito \\
\hline $\begin{array}{l}\text { Información } \\
\text { Con esta campaña la po- } \\
\text { blación será capaz de: } \\
\text { 1) Reconocer los frijoles } \\
\text { como un alimento de } \\
\text { alto valor nutritivo. }\end{array}$ & $\begin{array}{l}\text { Creencia de que los frijo- } \\
\text { les son equivalentes a los } \\
\text { cereales } \\
\text { Pensamiento de algunas } \\
\text { madres de que los frijoles } \\
\text { caen mal y engordan. }\end{array}$ & $\begin{array}{l}\text { Interés por conocer más } \\
\text { sobre el valor nutritivo de } \\
\text { los frijoles. } \\
\text { Muchas personas recono- } \\
\text { cen los frijoles como un } \\
\text { alimento de alto valor nu- } \\
\text { tritivo, pero desconocen } \\
\text { los nutrientes que pro- } \\
\text { veen. }\end{array}$ & $\begin{array}{l}\text { Los frijoles son un exce- } \\
\text { lente alimento, contienen } \\
\text { proteína, hierro, ácido fó- } \\
\text { lico, potasio, magnesio, } \\
\text { fósforo, zinc, fibra. } \\
\text { Los frijoles ayudan a pre- } \\
\text { venir la anemia porque } \\
\text { son ricos en hierro y ácido } \\
\text { fólico. } \\
\text { El hierro, la proteína y el } \\
\text { ácido fólico que contienen } \\
\text { los frijoles ayudan para el } \\
\text { crecimiento y la produc- } \\
\text { ción de defensas del orga- } \\
\text { nismo. } \\
\text { La fibra que contienen los } \\
\text { frijoles ayuda a mejorar la } \\
\text { digestión, a prevenir las en- } \\
\text { fermedades del corazón y } \\
\text { de las arterias, evita el es- } \\
\text { treñimiento y ayuda a man- } \\
\text { tener un peso adecuado. }\end{array}$ & $\begin{array}{l}\text { Con esta campaña la po- } \\
\text { blación será capaz de: } \\
\text { 1) Reconocer los frijoles } \\
\text { como un alimento de alto } \\
\text { valor nutritivo. }\end{array}$ \\
\hline $\begin{array}{l}\text { Actitudes } \\
\text { 1) Reafirmar la actitud } \\
\text { positiva que tienen } \\
\text { las madres hacia los } \\
\text { frijoles. }\end{array}$ & & $\begin{array}{l}\text { A la mayoría les gustan } \\
\text { los frijoles y los asocian } \\
\text { (los molidos), con paseos } \\
\text { y fiestas. }\end{array}$ & $\begin{array}{l}\text { Los frijoles son ricos, nu- } \\
\text { tritivos y saludables. }\end{array}$ & $\begin{array}{l}\text { Que las madres manten- } \\
\text { gan su actitud positiva ha- } \\
\text { cia los frijoles. }\end{array}$ \\
\hline $\begin{array}{l}\text { Comportamiento } \\
\text { 1) Consumir como míni- } \\
\text { mo } 5 \text { cucharadas de } \\
\text { frijoles al día. }\end{array}$ & $\begin{array}{l}\text { Pensamiento de que los } \\
\text { frijoles engordan. } \\
\text { Falta de tiempo para po- } \\
\text { ner los frijoles. } \\
\text { Comen menos de tres } \\
\text { comidas al día }\end{array}$ & $\begin{array}{l}\text { A las personas les gusta } \\
\text { consumir frijoles. } \\
\text { Es un alimento que se } \\
\text { puede utilizar en diferen- } \\
\text { tes preparaciones. }\end{array}$ & $\begin{array}{l}\text { Los frijoles se pueden co- } \\
\text { mer en cualquier momen- } \\
\text { to del día. } \\
\text { Los frijoles son un ali- } \\
\text { mento muy nutritivo por } \\
\text { lo que lo mejor es consu- } \\
\text { mir más de } 5 \text { cucharadas } \\
\text { de frijoles todos los días. } \\
\text { Prepare frijoles en } \\
\text { diferentes formas }\end{array}$ & $\begin{array}{l}\text { Que se consuman como } \\
\text { mínimo } 5 \text { cucharadas de } \\
\text { frijoles por persona al día. }\end{array}$ \\
\hline
\end{tabular}

Fuente: Martínez et al. 2000. Adaptado por el grupo de trabajo e investigadoras del Proyecto, 2000. 
Table 3. Part of matrix of the communication plan for the target group. Educational Campaign to increase bean consumption. Sabanilla de Montes de Oca, Costa Rica, 2000.

Audience: Mothers with school children

Communication strategy: Multimedia and interpersonal communication

General objective: To increase bean consumption in the community of Sabanilla

\begin{tabular}{|c|c|c|c|c|}
\hline Objectives & Barriers to change & Incentives to change & $\begin{array}{l}\text { Messages to be } \\
\text { delivered }\end{array}$ & Success indicator \\
\hline $\begin{array}{l}\text { Information } \\
\text { With this Campaign the } \\
\text { population will be able to: } \\
\text { 1) Acknowledge that } \\
\text { beans are highly } \\
\text { nutritious }\end{array}$ & $\begin{array}{l}\text { People's belief that beans } \\
\text { are a starchy food } \\
\text { equivalent to cereals }\end{array}$ & $\begin{array}{l}\text { Interest to know more } \\
\text { about the nutritional } \\
\text { value of beans } \\
\text { Many people acknowled- } \\
\text { ge that beans are highly } \\
\text { nutritious, but ignore the } \\
\text { nutrients they supply }\end{array}$ & $\begin{array}{l}\text { Beans are excellent, they } \\
\text { contain protein, iron, folic } \\
\text { acid,potassium, magne- } \\
\text { sium, phosphorus, zinc, } \\
\text { and fiber } \\
\text { Beans help prevent } \\
\text { anemia because they are } \\
\text { rich in iron and folic acid } \\
\text { Iron, protein, and folic } \\
\text { acid contained in beans } \\
\text { contribute to body growth } \\
\text { and creation of defenses } \\
\text { Fiber contained in beans } \\
\text { helps improve digestion, } \\
\text { prevent cardiovascular } \\
\text { diseases, prevents cons- } \\
\text { tipation, and helps } \\
\text { maintain an ideal weight }\end{array}$ & $\begin{array}{l}\text { Through this Campaign } \\
\text { the population would be } \\
\text { able to: } \\
\text { 1) Acknowledge that } \\
\text { beans are highly } \\
\text { nutritious }\end{array}$ \\
\hline $\begin{array}{l}\text { Attitudes } \\
\text { 1)Reinforce the positive } \\
\text { attitude that mothers have } \\
\text { towards beans }\end{array}$ & & $\begin{array}{l}\text { Most mothers like beans } \\
\text { and associate them with } \\
\text { happy ocassions }\end{array}$ & $\begin{array}{l}\text { Beans are delicious, } \\
\text { nutritious and healthful }\end{array}$ & $\begin{array}{l}\text { 1) Maintain mothers' } \\
\text { positive attitude towards } \\
\text { beans }\end{array}$ \\
\hline $\begin{array}{l}\text { Behavior } \\
\text { 1) Consume at least five } \\
\text { spoonfuls of beans per } \\
\text { day }\end{array}$ & $\begin{array}{l}\text { Belief that beans are } \\
\text { fattening } \\
\text { Lack of time to cook } \\
\text { beans } \\
\text { Make less than three } \\
\text { meals a day }\end{array}$ & $\begin{array}{l}\text { Persons like to eat beans } \\
\text { It can be prepared in } \\
\text { many ways }\end{array}$ & $\begin{array}{l}\text { Beans may be eaten at any } \\
\text { time of the day } \\
\text { Beans are very nutritious, } \\
\text { therefore it is good to eat } \\
\text { more than five spoonfuls } \\
\text { of beans per day } \\
\text { Prepare beans in different } \\
\text { ways }\end{array}$ & $\begin{array}{l}\text { 1) Eat at least five } \\
\text { spoonfuls of beans per } \\
\text { day }\end{array}$ \\
\hline
\end{tabular}

Source: Martínez et al. 2000. Adapted by the Project's work team and researchers, 2000.

Esta experiencia resulta de gran utilidad para mejorar aspectos específicos del patrón alimentario ya sea para introducir o incrementar alimentos funcionales (American Dietetic Association (ADA) 1999) como los frijoles o para otros alimentos cuyo consumo debería focusing on a single food, it is possible to get a deeper understanding of the socio-cultural context, and make a comprehensive approach, which does not only cover nutritional aspects, but also the pragmatic aspects and attitudes that would promote changes in the long term. 
limitarse. Al focalizar en un solo alimento, es posible profundizar en el contexto socio-cultural, y hacer un abordaje integral, que no solo cubra los aspectos nutricionales sino también los pragmáticos y de actitudes, que favorecen los cambios en el largo plazo.

\section{LITERATURA CITADA}

AMERICAN DIETETIC ASSOCIATION (ADA). 1999. Functional foods: position of ADA. JAM Diet Assoc 99: 1278-1285.

BOURGES, H. 1988. Costumbres, prácticas y hábitos alimentarios deseables e indeseables. Archivos Latinoamericanos de Nutrición, 39 (3): 767-779.

CAMPOS, E; FERNÁNDEZ, A; SÁNCHEZ, I; SANCHO, T.; VILLALOBOS, C. 1999. Diagnóstico para una Campaña educativa para aumentar el consumo de frijol en una comunidad del área urbana de clase media. Seminario de Licenciatura. San José, Costa Rica: Universidad de Costa Rica. 153 p.

DÍAZ-BARRIGA; HERNÁNDEZ, G. 2002. Estrategias docentes para un aprendizaje significativo: Una interpretación constructivista (2da ed). México: McGraw Hill. p. 465 .

DUMANI, M.; PÁEZ, P. 2004. Efectos de una Campaña educativa sobre frijoles en un grupo de mujeres. Agronomía Mesoamericana 15(3): 365-378.

; RODRÍGUEZ, S. 2004. Proceso de determinación de prácticas nutricionales recomendables con respecto a los frijoles. Revista Costarricense de Salud Pública. Año $13 \mathrm{~N}^{\circ} 24:$ 32-38.

FAO. 1996. Guía metodológica de comunicación social en nutrición. Roma, Italia: FAO. p. 101.

INCAP/ICNND/ Ministerio de Salubridad Pública de Costa Rica. 1969. Evaluación Nutricional de la Población de Centroamérica y Panamá: Costa Rica. Publicación INCAP-V-28. Guatemala, Guatemala: INCAP. 113 p.

MARTÍNEZ, T; MURILLO, A; PÁEZ, P; RODRÍGUEZ, S. 2000. Elaboración de los contenidos de los mensajes educativos para aumentar el consumo de frijoles en una comunidad del área urbana de clase media. Seminario de Licenciatura. San José, Costa Rica. Universidad de Costa Rica. 103 p.

MINISTERIO DE SALUD. 1979. Encuesta Nacional de Nutrición. San José, Costa Rica: Ministerio de Salud. p.45.

1986. Encuesta Nacional de Nutrición. Evaluación Dietética. San José, Costa Rica: Ministerio de Salud. $63 \mathrm{p}$.

\section{REFERENCES}

AMERICAN DIETETIC ASSOCIATION (ADA). 1999. Functional foods: position of ADA. JAM Diet Assoc 99: 1278-1285.

BOURGES, H. 1988. Costumbres, prácticas y hábitos alimentarios deseables e indeseables. Archivos Latinoamericanos de Nutrición, 39 (3): 767-779.

CAMPOS, E; FERNÁNDEZ, A; SÁNCHEZ, I; SANCHO, T.; VILLALOBOS, C. 1999. Diagnóstico para una Campaña educativa para aumentar el consumo de frijol en una comunidad del área urbana de clase media. Seminario de Licenciatura. San José, Costa Rica: Universidad de Costa Rica. 153 p.

DÍAZ-BARRIGA; HERNÁNDEZ, G. 2002. Estrategias docentes para un aprendizaje significativo: Una interpretación constructivista (2da ed). México: McGraw Hill. p. 465.

DUMANI, M.; PÁEZ, P. 2004. Efectos de una Campaña educativa sobre frijoles en un grupo de mujeres. San José, Costa Rica. Agronomía Mesoamericana 15(3): 365-378.

; RODRÍGUEZ, S. 2004. Proceso de determinación de prácticas nutricionales recomendables con respecto a los frijoles. Revista Costarricense de Salud Pública. Año 13, $\mathrm{N}^{\circ}$ 24: 32-38.

FAO. 1996. Guía metodológica de comunicación social en nutrición. Roma, Italia: FAO. p. 101.

INCAP/ICNND/ Ministerio de Salubridad Pública de Costa Rica. 1969. Evaluación Nutricional de la Población de Centroamérica y Panamá: Costa Rica. Publicación INCAP-V-28. Guatemala, Guatemala: INCAP. 113 p.

MARTÍNEZ, T; MURILLO, A; PÁEZ, P; RODRÍGUEZ, S. 2000. Elaboración de los contenidos de los mensajes educativos para aumentar el consumo de frijoles en una comunidad del área urbana de clase media. Seminario de Licenciatura. San José, Costa Rica. Universidad de Costa Rica. 103 p.

MINISTERIO DE SALUD. 1979. Encuesta Nacional de Nutrición. San José, Costa Rica: Ministerio de Salud. p.45.

1986. Encuesta Nacional de Nutrición. Evaluación Dietética. San José, Costa Rica: Ministerio de Salud. $63 \mathrm{p}$.

1996. Encuesta Nacional de Nutrición. Fascículo 3: Consumo Aparente. San José, Costa Rica.p. 45.

MURILLO, A.; RODRÍGUEZ, S. 2004. Conocimientos, actitudes y prácticas de madres de escolares con respecto a frijoles. Agronomía Mesoamericana 15(3): 277-289. 
1996. Encuesta Nacional de Nutrición. Fascículo 3: Consumo Aparente. San José, Costa Rica.p. 45.

MURILLO, A.; RODRÍGUEZ, S. 2004. Conocimientos, actitudes y prácticas de madres de escolares con respecto a frijoles. Agronomía Mesoamericana 15(3): 277-289.

RODRÍGUEZ, L.; RODRÍGUEZ, S. 2003. Consumo de frijoles y atención en salud de familias de una comunidad urbana de Costa Rica. Revista Costarricense de Salud Pública. Año 12, N²3: 47-51.

2004. Efectos de una Campaña educativa sobre frijoles en escolares. Agronomía Mesoamericana 15(3): 379-392.

; PÁEZ, P. 2004. Incremento del consumo de frijoles en una población urbana por medio de una Campaña educativa. Agronomía Mesoamericana 15(3):357-363.

RODRÍGUEZ, S.; MURILLO, A. 2004 a. Conocimientos, actitudes y prácticas de escolares con respecto a frijoles. San José, Costa Rica. Agronomía Mesoamericana 15(3): 291-300.

RODRÍGUEZ, S.; MURILLO, A. 2004 b. Frijoles: prácticas factibles para madres de escolares. Agronomía Mesoamericana 15 (3): 301-313.

SCHETJMAN, A. 1994. Economía política de los sistemas alimentarios en América Latina. Chile: Organización de Las Naciones Unidas para la Agricultura y la Alimentación. p. 252.
RODRÍGUEZ, L.; RODRÍGUEZ, S. 2003. Consumo de frijoles y atención en salud de familias de una comunidad urbana de Costa Rica. Revista Costarricense de Salud Pública. Año 12, $\mathrm{N}^{\circ}$ 23: 47-51.

;. 2004. Efectos de una Campaña educativa sobre frijoles en escolares. Agronomía Mesoamericana 15(3): 379-392.

; PÁEZ, P. 2004. Incremento del consumo de frijoles en una población urbana por medio de una Campaña educativa. Agronomía Mesoamericana 15(3):357-363.

RODRÍGUEZ, S.; MURILLO, A. 2004 a. Conocimientos, actitudes y prácticas de escolares con respecto a frijoles. San José, Costa Rica. Agronomía Mesoamericana 15(3): 291-300.

RODRÍGUEZ, S.; MURILLO, A. 2004 b. Frijoles: prácticas factibles para madres de escolares. Agronomía Mesoamericana 15 (3): 301-313.

SCHETJMAN, A. 1994. Economía política de los sistemas alimentarios en América Latina. Chile: Organización de Las Naciones Unidas para la Agricultura y la Alimentación. p. 252. 